\title{
TAXUS WALLICHIANA (HIMALAYAN YEW) FOR THE LIVELIHOOD OF LOCAL PEOPLE IN SOME PROTECTED AREAS OF NEPAL
}

\author{
JYOTI PRASAD GAJURELํㅛ, KRISHNA KUMAR SHRESTHA ${ }^{1}$, \\ SILKE WERTH² AND CHRISTOPH SCHEIDEGGER ${ }^{3}$
}

\begin{abstract}
${ }^{1}$ Central Department of Botany, Tribhuvan University, Kirtipur, Kathmandu, Nepal WSL Swiss Federal Research Institute, Zürcherstrasse 111, CH-8903 Birmensdorf, Switzerland.,

${ }^{2}$ Faculty of Life and Environmental Sciences, University of Iceland, Sturlugata 7, 101 Reykjavík, Iceland 2Institute for Plant Sciences, University of Graz, Holteigasse 6, 8010 Graz, Austria ${ }^{3}$ WSL Swiss Federal Research Institute, Zürcherstrasse 111, CH-8903 Birmensdorf, Switzerland
\end{abstract} gajurelomjyoti@yahoo.com

\section{ABSTRACT}

Nepal is a small country but diverse in ethnic communities living in different parts of the country. These ethnic communities have been practicing the indigenous knowledge of plants for their livelihood. The objective of this study is to document the traditional knowledge of one of the most important medicinal plant species Taxus wallichiana Zucc. in different altitudinal gradients in Manaslu Conservation Area, Sagarmatha National Park and surrounding and Kanchenjunga Conservation Area. This study was carried out in six altitudinal gradients $(2200 \mathrm{~m}$ asl to 3800 masl) with altitudinal steps of $400 \mathrm{~m}$ asl. We used direct observation method and standardized interviews to collect the data related to the use of $T$. wallichiana. Out of five caste groups, only four were local to the site while one cast had migrated from Terai region and had settled down recently. The four caste groups included Sherpa, Tamang, Rai and Gurung who have been using the plant products for various reasons. People used the species as timber, medicine for jaundice and cancer, fence, construction material for houses and cattle fodder. Knowledge of the use of $T$. wallichiana was mainly available at an altitude of $2600 \mathrm{~m}$ a.s.l., the species altitudinal distribution optimum. Most of the informants were related to community forests in the study areas and many also depend on plants for their livelihood. This study also helped the local people by informing them about sustainable use and conservation of this plant in the study areas.

Keywords: ethnic communities, traditional knowledge, altitudinal gradient, plant use

\section{INTRODUCTION}

Nepal is a small landlocked country rich in biodiversity as well as traditional use of plants. Each ethnic group has developed traditional knowledge about the use and ecology of plants, which are important for the groups' livelihood (Mac et al., 2005) and the use of medicinal plants in developing countries provides a primary health care system (Alexiades et al., 1996). In Nepal, the people from remote areas have been using plants for various purposes (Bhattarai, 1992). There is an urgent need to preserve this valuable traditional knowledge and support ethnic 
groups in the sustainable use of these natural resources (Kunwar et al., 2013).

Taxus wallichiana Zucc. is a small to medium-sized, evergreen tree ranging in altitude from $2200 \mathrm{~m}$ to $3400 \mathrm{~m}$ asl (Press et al., 2000). This species has a high economic importance and is mainly used for furniture, incense, fodder (Thomas \& Farjon, 2011).Taxus wallichiana is also a very important source of paclitaxel which is a cancer inhibiting compound (Mukherjee et al., 2002). The unique geographical features of the study sites which are in remote places of Nepal support local people to use their indigenous knowledge in different ways. The main objective of this study is to report the traditional use of $T$. wallichiana in the study areas and to document how this relates to people's livelihoods. This study also aims at making local people aware of conservation of the species in the area so that overexploitation of this species can be minimized without affecting their livelihood.

\section{Study area}

The study sites includes the two valleys Nubri (MCA1) and Tsum (MCA2) located in Manaslu Conservation Area, Sagarmatha (SNP1) and Dudkunda (SNP2) valleys in the Sagarmatha National Park and surroundings and Olangchungola (KCA1) and Ghunsa (KCA2) valleys in the Kanchenjunga Conservation Area (map 1).

\section{MATERIALS AND METHODS}

The altitudinal gradients included settlements at four altitudinal zones, i.e. at $2200 \mathrm{~m}$ asl, 2600 $\mathrm{m}$ asl, $3000 \mathrm{~m}$ asl, $3400 \mathrm{~m}$ asl, and $3800 \mathrm{~m}$ asl. In total 26 sites were visited from 2011 to 2013. DIVA GIS-7.5 was used for making maps of the study sites (Hijmans et al., 2012).

The selection of focal ethnic groups were mostly based on their membership of community forests or conservation areas. Besides, some other people not belonging to the collection sites were also interviewed to gather additional information. We applied standard interviews (Alexiades et al., 1996) and direct field observations (Martin, 1995). All the information was entered in a spreadsheet (Microsoft, 2010). The information related to caste group and the use mentioned by each group were added in the rows and columns respectively. For each sites, the information on the uses were recorded in a spreadsheet on column. We also used pivot table to analyse the data. The results were compared with a review of the published literature. The collected specimens were identified with standard literatures including Polunin \& Stainton (1984), Möller et al. (2007) and Farjon (2010). The specimens were deposited in the National Herbarium and Plant Laboratories, Godawari, Nepal. After the interviews local people were informed about the importance and conservation priority of this species in the study area.

\section{RESULTS}

We collected field observations and carried out interviews at 27 localities in the Nubri (MCA1) and Tsum (MCA2) valleys in Manaslu region, Sagarmatha (SNP1) and Dudkunda (SNP2) valleys in Sagarmatha region and Olangchungola (KCA1) and Ghunsa (KCA2) valleys in Kanchenjunga region (Fig. 1). 


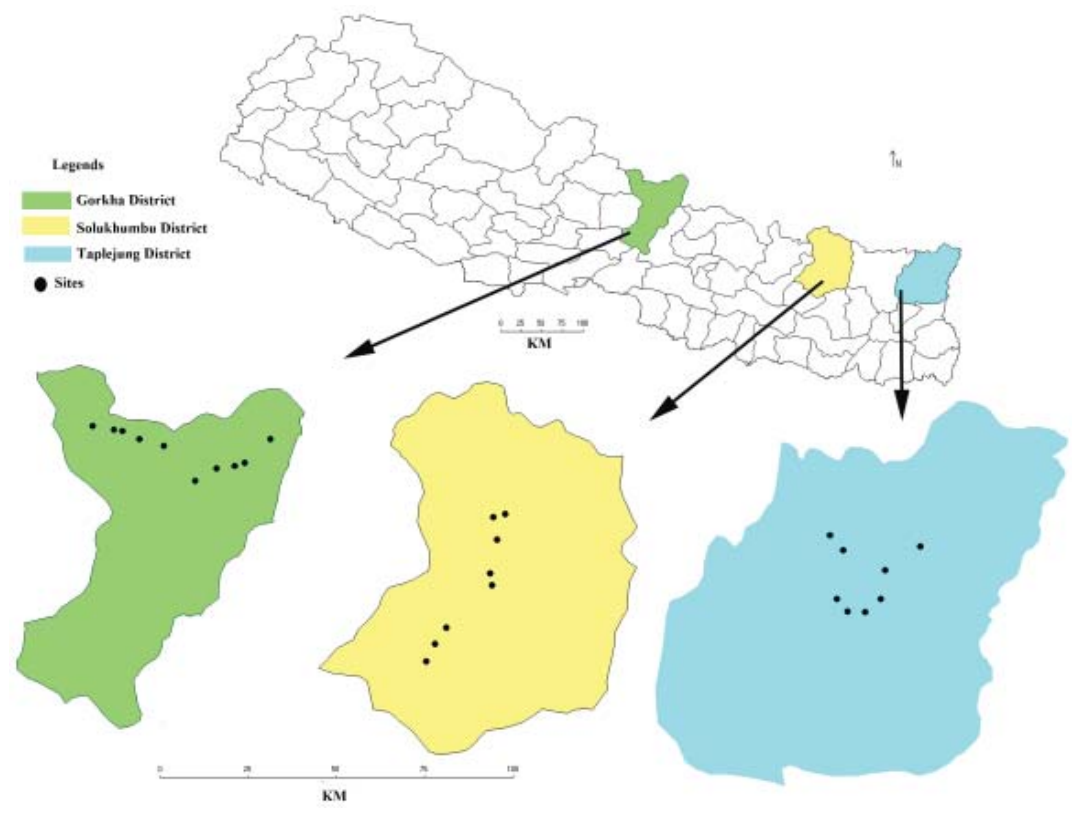

FIG.1. Study sites included Manaslu region (Nubri and Ghunsa Valleys),

Sagarmatha region (Sagarmatha and Dudkunda Valleys) and Kanchenjunga region (Olangchungola and Ghunsa Valleys).

A total of 26 key informants where interviewed in the study sites which included three women and 23 men. A total of five caste groups were interviewed, of which one caste group was not native to the study area (table 1).

TABLE 1. Caste groups and use of Taxus wallichiana in the study sites.

\begin{tabular}{|l|c|c|c|c|c|c|c|c|}
\hline \multirow{2}{*}{$\begin{array}{c}\text { Caste } \\
\text { Groups }\end{array}$} & \multicolumn{7}{|c|}{ Use } \\
\cline { 2 - 9 } & Timber & $\begin{array}{c}\text { Timber } \\
\text { to Tibet }\end{array}$ & Fence & $\begin{array}{c}\text { Cattle } \\
\text { Fodder }\end{array}$ & $\begin{array}{c}\text { Leaf } \\
\text { or Bark }\end{array}$ & $\begin{array}{c}\text { Construction } \\
\text { of House }\end{array}$ & $\begin{array}{c}\text { Medicine } \\
\text { in cancer }\end{array}$ & $\begin{array}{c}\text { Medicine } \\
\text { in jaundice }\end{array}$ \\
\hline Lama & 5 & 2 & 2 & 1 & 7 & & & \\
\hline Rai & 1 & & & & 1 & & & \\
\hline Sherpa & 2 & 1 & & & 3 & 2 & 2 & 1 \\
\hline Tamang & & & & & 1 & & & \\
\hline Thapa & & & & & & & & \\
\hline Grand Total & 8 & 3 & 2 & 1 & 12 & 2 & 2 & 1 \\
\hline
\end{tabular}

Note: Number indicates total sites. 
Taxus wallichiana was used for multiple purposes in the study areas and included cattle fodder, fence making, leaf and bark collection, timber for local use, timber for sale in Tibet, construction of house, medicine for cancer and jaundice (table 1).

According to informants, the most common use was to sell leaf and bark at the market together with timber. The least common practice was making fence, using cattle fodder and consuming directly as medicine (table 2).

TABLE 2. Use pattern in different altitudinal zones in the studied valleys.

\begin{tabular}{|c|c|c|c|c|c|c|c|c|c|c|c|c|c|c|c|}
\hline \multirow{2}{*}{ SN } & \multirow{2}{*}{ Locality } & \multirow{2}{*}{ Valley } & \multirow{2}{*}{ Valley Name } & \multirow{2}{*}{ Region } & \multirow{2}{*}{$\begin{array}{c}\text { Alt. } \\
\text { Zone } \\
\text { m }\end{array}$} & \multirow{2}{*}{ Caste } & \multicolumn{8}{|c|}{ Uses } & \multirow{2}{*}{$\begin{array}{l}\text { Do Not } \\
\text { Know }\end{array}$} \\
\hline & & & & & & & 1 & 2 & 3 & 4 & 5 & 6 & 7 & 8 & \\
\hline 1 & Gap 11 & MCA1 & Nubri & MCA & 2200 & Lama & 1 & & & & 5 & & & & \\
\hline 2 & Namrung 12 & MCA1 & Nubri & MCA & 2600 & Lama & 1 & & 3 & 4 & 5 & & & & \\
\hline 3 & Sho 13 & MCA1 & Nubri & MCA & 3000 & Lama & & 2 & 3 & & 5 & & & & \\
\hline 4 & Lho 14 & MCA1 & Nubri & MCA & 3400 & Lama & & 2 & & & 5 & & & & \\
\hline 5 & Samagaon 15 & MCA1 & Nubri & MCA & 3800 & Lama & & & & & & & & & $\begin{array}{l}\text { Do Not } \\
\text { Know }\end{array}$ \\
\hline 6 & Surke 21 & SNP1 & Sagarmatha & SNP & 2200 & Sherpa & & 2 & & & & 6 & & & \\
\hline 7 & Musae 22 & SNP1 & Sagarmatha & SNP & 2600 & Sherpa & & & & & & & & & $\begin{array}{l}\text { Do Not } \\
\text { Know }\end{array}$ \\
\hline 8 & Jorsalle 23 & SNP1 & Sagarmatha & SNP & 3000 & Lama & & & & & & & & & $\begin{array}{l}\text { Do Not } \\
\text { Know }\end{array}$ \\
\hline 9 & Lausasa 24 & SNP1 & Sagarmatha & SNP & 3400 & Sherpa & & & & & & & & & $\begin{array}{l}\text { Do Not } \\
\text { Know }\end{array}$ \\
\hline 10 & Khumjung 25 & SNP1 & Sagarmatha & SNP & 3800 & Sherpa & & & & & & & & & $\begin{array}{l}\text { Do Not } \\
\text { Know }\end{array}$ \\
\hline 11 & Ilagaon 31 & KCA1 & Olangchungola & $\mathrm{KCA}$ & 2200 & Rai & 1 & & & & 5 & & & & \\
\hline 12 & Jongin 32 & KCA1 & Olangchungola & $\mathrm{KCA}$ & 2600 & Sherpa & & & & & 5 & & & & \\
\hline 13 & $\begin{array}{c}\text { Olangchungola } \\
33\end{array}$ & KCA1 & Olangchungola & KCA & 3000 & Sherpa & 1 & & & & 5 & & & & \\
\hline 14 & Chumling 41 & MCA2 & Tsum & MCA & 2200 & Lama & 1 & & & & 5 & & & & \\
\hline 15 & Gho 42 & MCA2 & Tsum & MCA & 2600 & Lama & 1 & & & & 5 & & & & \\
\hline 16 & Chekamparo 43 & MCA2 & Tsum & MCA & 3000 & Lama & 1 & & & & 5 & & & & \\
\hline 17 & Nile 44 & MCA2 & Tsum & MCA & 3400 & Lama & & & & & & & & & $\begin{array}{l}\text { Do Not } \\
\text { Know }\end{array}$ \\
\hline
\end{tabular}




\begin{tabular}{|l|c|c|c|c|c|c|c|c|c|c|c|c|c|c|}
\hline $\mathbf{1 8}$ & Boldok 51 & SNP2 & Dudkunda & SNP & 2200 & Tamang & & & 5 & & & \\
\hline $\mathbf{1 9}$ & Phera 52 & SNP2 & Dudkunda & SNP & 2600 & Sherpa & & & & 6 & 7 & 8 & \\
\hline $\mathbf{2 0}$ & Gonbo 53 & SNP2 & Dudkunda & SNP & 3000 & Sherpa & & & & & & $\begin{array}{c}\text { Do Not } \\
\text { Know }\end{array}$ \\
\hline $\mathbf{2 1}$ & Taksindo 54 & SNP2 & Dudkunda & SNP & 3400 & Thapa & & & & & & $\begin{array}{c}\text { Do Not } \\
\text { Know }\end{array}$ \\
\hline $\mathbf{2 2}$ & Sekathum 61 & KCA2 & Tsum & KCA & 2200 & Sherpa & & & & & & & & $\begin{array}{c}\text { Do Not } \\
\text { Know }\end{array}$ \\
\hline $\mathbf{2 3}$ & Lamatar 62 & KCA2 & Tsum & KCA & 2600 & Rai & & & & & & $\begin{array}{c}\text { Do Not } \\
\text { Know }\end{array}$ \\
\hline $\mathbf{2 4}$ & Amjelosa 62 & KCA2 & Tsum & KCA & 2600 & Sherpa & 1 & & & 5 & & & $\begin{array}{c}\text { Do Not } \\
\text { Know }\end{array}$ \\
\hline $\mathbf{2 5}$ & Gyabla 63 & KCA2 & Tsum & KCA & 3000 & Sherpa & & & & & 7 & \\
\hline $\mathbf{2 6}$ & Ghunsa 64 & KCA2 & Tsum & KCA & 3400 & Sherpa & & & & & & $\begin{array}{c}\text { Do Not } \\
\text { Know }\end{array}$ \\
\hline
\end{tabular}

Note: 1: Timber, 2: Timber to Tibet, 3: Fence, 4: Cattle Fodder, 5: Leaf/Bark, 6: Construction of House, 7: Medicine in cancer, 8: Medicine in jaundice.

People at altitudes of $2200 \mathrm{~m}$ asl and $3400 \mathrm{~m}$ asl had less use of the species (table 3). The maximum use was at $2600 \mathrm{~m}$ asl according to informants (table 3 ). There were no settlements at $3800 \mathrm{~m}$ asl except SNP1 and MCA1. But local people at these altitudes had no information about the use of the species (table 3). It was also found that most of the information was obtained from the valleys of Manaslu CA and least from valleys of Sagarmatha NP and surroundings (table 3).

TABLE 3. Use of Taxus wallichiana (+) in each valley and altitudinal zone.

\begin{tabular}{|c|c|c|c|c|c|c|c|c|}
\hline \multirow{2}{*}{$\begin{array}{c}\text { Valleys in } \\
\text { Altitudinal } \\
\text { Zone }\end{array}$} & \multicolumn{8}{|c|}{ Use } \\
\hline & Timber & $\begin{array}{l}\text { Timber } \\
\text { to Tibet }\end{array}$ & Fence & $\begin{array}{l}\text { Cattle } \\
\text { Fodder }\end{array}$ & $\begin{array}{l}\text { Leaf/ } \\
\text { Bark }\end{array}$ & $\begin{array}{c}\text { Construction } \\
\text { of House }\end{array}$ & $\begin{array}{l}\text { Medicine } \\
\text { in cancer }\end{array}$ & $\begin{array}{c}\text { Medicine in } \\
\text { Jaundice }\end{array}$ \\
\hline $2200 \mathrm{~m}$ & 3 & 1 & & & 4 & 1 & & \\
\hline KCA1 & + & & & & + & & & \\
\hline KCA2 & & & & & & & & \\
\hline MCA1 & + & & & & + & & & \\
\hline MCA2 & + & & & & + & & & \\
\hline SNP1 & & + & & & & + & & \\
\hline
\end{tabular}




\begin{tabular}{|c|c|c|c|c|c|c|c|c|}
\hline SNP2 & & & & & 1 & & & \\
\hline $2600 \mathrm{~m}$ & 3 & & 1 & 1 & 4 & 1 & 1 & 1 \\
\hline KCA1 & & & & & + & & & \\
\hline KCA2 & + & & & & + & & & \\
\hline MCA1 & + & & + & + & + & & & \\
\hline MCA2 & + & & & & + & & & \\
\hline \multicolumn{9}{|l|}{ SNP1 } \\
\hline SNP2 & & & & & & + & + & + \\
\hline $3000 \mathrm{~m}$ & 2 & 1 & 1 & & 3 & & 1 & \\
\hline KCA1 & + & & & & + & & & \\
\hline KCA2 & & & & & & & + & \\
\hline MCA1 & & + & + & & + & & & \\
\hline MCA2 & + & & & & + & & & \\
\hline \multicolumn{9}{|l|}{ SNP1 } \\
\hline \multicolumn{9}{|l|}{ SNP2 } \\
\hline $3400 \mathrm{~m}$ & & 1 & & & 1 & & & \\
\hline \multicolumn{9}{|l|}{ KCA2 } \\
\hline MCA1 & & + & & & + & & & \\
\hline \multicolumn{9}{|l|}{ MCA2 } \\
\hline \multicolumn{9}{|l|}{ SNP1 } \\
\hline \multicolumn{9}{|l|}{ SNP2 } \\
\hline \multicolumn{9}{|l|}{$3800 \mathrm{~m}$} \\
\hline \multicolumn{9}{|l|}{ MCA1 } \\
\hline \multicolumn{9}{|l|}{ SNP1 } \\
\hline Grand Total & 8 & 3 & 2 & 1 & 12 & 2 & 2 & 1 \\
\hline
\end{tabular}

\section{DISCUSSION}

Our study revealed that different local caste groups (Tamang, Rai, Sherpa and Gurung) used $T$. wallichiana for multiple purposes in the study regions. The species has been used as cattle fodder, in fence making, as timber for local use as well as for sale to Tibet, as construction material for house and as medicine for cancer and jaundice. One of the interesting information 
was the sale of timber to Tibet adjacent to the Nubri valley of Manaslu CA and Sagarmatha valley of Sagarmatha NP and surrounding. This helped the people to improve their livelihood by increasing income. This practice was common in Nubri valley of Manaslu CA.

The most important use of $T$. wallichiana for the local people was timber. This finding was similar to the findings of Joshi (2009) who found that the use of the species as timber in the Eastern Nepal. Less important uses included timber for making fence posts and medicine.

The use of $T$. wallichiana as medicine for jaundice has not been reported from other studies in Nepal. However, Bhattarai et al. (2010) on their study in Mustang district of Nepal reported the use of the species as fence and medicine for cancer.

The local people living at an elevation of $2600 \mathrm{~m}$ asl had the most intensive use of the species while people from lower and higher parts of altitudinal gradients utilized the species less, possibly due to decreased availability of $T$. wallichiana below $2200 \mathrm{~m}$ asl and above $3400 \mathrm{~m}$ asl. People from valleys of Manaslu CA had more information on the use of the species while those from valleys of Sagarmatha NP and surroundings had less information, which may be due to their relatively high income from the touristic sector.

Our study also found during the interview that the local people collected large amount of the leaves from Nubri valley (MCA1) and Dudkunda valley (SNP2), as asked by multinational companies. But later, the companies did not buy. Based on interview, it was found that they could not sell and use the harvested leaves; which remained dumped in one or other ways.

Although this species plays an important role in the livelihood of local people in the study sites, people were not aware of ways for a sustainable harvest of the tree species. For the sustainable harvesting, people should not cut down the whole plant instead; they could collect the leaves from the branches of the old tree. People should try to collect the seeds and show them on soil so that the natural regeneration of the plant could be maintained. This study also provided the local people with information related to conservation of the species so that the local people shall be able to obtain a benefit from this natural resource through sustainable harvest.

\section{ACKNOWLEDGEMENTS}

This study was supported by the Swiss National Science Foundation (grant JRPIZ70Z0_131338/1 to CS). Thanks are also due to the faculty and staffs of Central Department of Botany, Tribhuvan University, for their cooperation. We are grateful to the Department of National Parks and Wildlife Conservation, Ministry of Forest and Soil Conservation, Government of Nepal and the National Trust for Nature Conservation, Nepal for providing permits in the study sites. Dr. Silke Werth was supported by a Marie Curie Fellowship (Lichenomics) within the program FP7 of the European Commission. We would like to thank Dr. Michael Nobis, Mr. Sanjeev Kumar Rai, Mr. Shiva Devkota and Mr. Bhim Rai for their support and help during the field work. This study would not have been possible without the help of local people of the study area.

\section{REFERENCES}

ALEXIADES, M N; SHELDON, J W (1996) Selected guidelines for ethnobotanical research:

a field manual. New York Botanical Garden, New York, USA. 
BHATTARAI, N K (1992) Medical ethnobotany in the Karnali zone, Nepal. Economic Botany 45(3): 257-261.

BHATTARAI, S; CHAUDHARY, R; QUAVE, C; TAYLOR, R (2010) The use of medicinal plants in the trans-Himalayan arid zone of Mustang district, Nepal. Journal of Ethnobiology and Ethnomedicine 6(14): 1-11.

FARJON, A (2010) A handbook of the world's conifers. Leiden: Brill,New York, USA. HIJMANS, R J; GUARINO, L; MATHUR, P (2012) DIVA-GIS version 7.5 manual [http://www. diva-gis.org/ accessed: 10. 07. 2014.

JOSHI, K (2009) Taxus wallichiana (Himalayan Yew: Loth salla) in Nepal : indigenous uses, conservation and agenda for sustainable management. Ethnobotanical Leaflet 13:150408.

KUNWAR, R M; MAHAT, L; ACHARYA, R P; BUSSMANN, R W (2013) Medicinal plants, traditional medicine, markets and management in far-west Nepal. Journal of Ethnobiology and Ethnomedicine 9(24):1-10.

MAC, M J; GARC, E; JAI, P (2005) An ethnobotanical survey of medicinal plants commercialized in the markets of La Paz and El Alto, Bolivia 97:337-350. doi: 10.1016/j.jep.2004.11.022 MARTIN, G J (1995) Ethnobotany: a methods manual. Chapman and Hall, London, UK. MICROSOFT (2010). Microsoft Excel [computer software]. Redmond, Washington: Microsoft. MÖLLER, M; GAO, L M; MILL, R R; LI, D Z; HOLLINGSWORTH, M L; GIBBY, M (2007) Morphometric analysis of the Taxus wallichiana complex (Taxaceae) based on herbarium material. Botanical Journal of the Linnean Society 155: 307-335.

MUKHERJEE, S; GHOSH, B; JHA, T B; JHA, S (2002) Variation in content of taxol and related taxanes in eastern Himalayan populations of Taxus wallichiana. Planta Medica 68: 757-759.

POLUNIN, O; STAINTON, A (1984) Flowers of the Himalaya. Oxford University Press, Oxford, UK.

PRESS, J R; SHRESTHA, K K; SUTTON, D A (2000) Annotated checklist of the flowering plants of Nepal. The Natural History Museum, London, UK.

THOMAS, P; FARJON, A (2011) Taxus wallichiana. In IUCN 2013. IUCN Red List of Threatened Species.version 2013.2. <www.iucnredlist.org>. Downloaded on 20 April 2014. 